\title{
The European origins of the Israeli-Palestinian economic union: A genealogical approach
}

\section{Jamie Levin}

Jamie Levin is the Israel Institute Post-Doctoral Fellow at the Henry M. Jackson School of International Studies, University of Washington, Seattle, WA, USA. He may best be reached at jamie.levin@mail.utoronto.ca.

\section{Abstract}

The Oslo peace process established a modified economic union between Israel and the Palestinian Authority. Economic unions require extensive collaboration and are generally found between states that enjoy pacific relations and are looking to deepen integration and political ties. The choice of an economic union between these adversaries is puzzling given that the aim of the peace process was to disentangle Israelis and Palestinians by establishing two separate states. Today, after the optimism surrounding the process has faded, it is easy to see the arrangement as a perpetuation of Israeli control over Palestinian life. However, such assessments fail to consider, first, the depth of the negotiations; second, the significant differences between the outcome of the negotiations and what was previously imposed by Israel; and, third, the gap between what was negotiated and what was later implemented. This article traces the genealogy of the economic union by exploring all three factors. While the negotiators did not start with a tabula rasa, they attempted to alter the existing economic arrangement along the European neo-functionalist model of integration. This approach was later largely abandoned, and what followed bore little resemblance to the positive spillover effects in Europe.

Practical men, who believe themselves to be quite exempt from any intellectual influences, are usually the slave of some defunct economist. Madmen in authority who hear voices in the air are distilling their frenzy from some academic scribbler of years back.

—John Maynard Keynes, The General Theory of Employment, Interest and Money

$\Lambda_{1}^{n}$ $n$ often overlooked feature of the Oslo peace process is that it established a modified economic union between Israel and the newly established PLO-run Palestinian Authority. Economic unions require extensive collaboration and typically are established to increase economic efficiency. They are generally created by states that enjoy pacific relations and are looking to deepen integration and entrench their political ties. The choice of an economic union to govern economic relations between longstanding adversaries is therefore puzzling given that the prima facie aim of the peace process was to disentangle Israelis and Palestinians by setting them on the road to establishing separate states. Yet integration during the interim period drew the parties closer together.

Numerous studies have discussed the economic framework of the Oslo peace process subsequent to its breakdown, but few studies have systematically explored why an economic union was picked over other available options in the first place. The optimism surrounding the peace process has long since faded, and today it is easy to see this arrangement as a perpetuation of Israeli control over daily Palestinian life, contrary to the spirit if not the letter of the agreements. Indeed, several authors have come to the conclusion that the economic arrangement was little more than an extension of conditions that Israel imposed after occupying Palestinian territories in 1967. However, such post-hoc assessments generally fail to seriously consider, first, the intense and far-ranging negotiations that led to the economic protocol, second, the significant differences between the economic arrangement captured in the protocol and the economic arrangement unilaterally imposed on the Palestinian territories by Israel post-1967, and third, the substantial gap between what was negotiated and what was ultimately implemented on the ground. I propose to fill these gaps. ${ }^{1}$

This article traces the evolution of the Israeli-Palestinian economic relationship from the start of the Oslo peace process to the present by exploring all three factors. In so doing, I employ a genealogical sensibility. Broadly, a genealogical approach focuses on the power of discourse over received knowledge. It is a historical method that explores how discourse gives rise to currently accepted truths. It looks to the past to uncover how the present view of history is shaped by the power of ideas; it is a "history of the present," as it were. A genealogical approach allows one to reevaluate assumptions that give rise to contested meanings of the present. It is, in this 
sense, a method of counter-history. ${ }^{2}$

The negotiators did not start with a tabula rasa. I argue that they attempted to alter the existing economic arrangement by deepening Israeli-Palestinian integration along the lines of a European neo-functionalist model that would provide Palestinians with greater economic autonomy through the ability to independently raise revenue, pursue local economic development, and trade with neighboring Arab states with whom Israel enjoyed no economic relations. This was to be a substantial departure from the economic arrangements imposed by Israel post-1967. The explicit hope was that increased economic integration would create positive spillover effects, much as had been seen in Europe in the post-war era. As such, the Oslo peace process is a diagnostic case of the diffusion of ideas-from Europe to the Middle East-in international relations. I also argue that there was great slippage between what was negotiated and what was implemented. Although never officially repudiated, many aspects of the newly minted protocol were abandoned following a wave of suicide bombings aimed at Israeli civilians and the subsequent election of a right-wing, Likud government headed by Benjamin Netanyahu in 1996. What followed bore little resemblance to the neo-functionalist model. Indeed, the Palestinian economy remains weakened and subordinate to Israeli control. ${ }^{3}$

I rely on three main sources of evidence. First are the peace accords, all of which are publicly available. Second, I make use of semi-structured interviews I conducted with key informants, including substantially all of the Palestinian and Israeli negotiators of the Oslo peace process and their Norwegian mediator. Third, to supplement the interviews I rely on a small number of political memoirs that provide first-hand accounts of the negotiations. Because actors are said to have powerful incentives to withhold or misrepresent private information, I treat these sources with caution, triangulating evidence where possible to increase confidence in my findings. ${ }^{4}$

The Israeli-Palestinian peace process has been studied extensively, yet the role of the European approach to integration is not well-covered. As compared to the United States, there is a tendency to see Europe as having had a negligible impact during the Oslo peace process, particularly in its nascent stages. In contrast, I show in this article that Europe has had a significant effect on the character of the negotiations, namely in the context of the economic union between Israel and the Palestinian Authority (PA). Addressing this impact in detail will help shed light not only on the Israeli-Palestinian peace process but also on economic integration, international cooperation, treaty-making, and peacemaking in general. ${ }^{5}$
Economic unions require extensive collaboration. Typically, they are created by states that enjoy pacific relations and are looking to deepen integration and entrench political ties. The choice of an economic union to govern economic relations between longstanding adversaries is therefore puzzling given that the prima facie aim of the Oslo peace process was to disentangle Israelis and Palestinians by setting them on the road to establishing separate states. This article traces the evolution of the idea of an economic union-from conception to negotiation and implementation-between Israel and the Palestinian Territories.

\section{The Paris Protocol}

In 1993, Israel and the Palestinian Liberation Organization (PLO) signed the first of a series of interim agreements, known as the Oslo Accord. The Accords put an end to the intifada, as well as to the local movement to boycott Israeli goods and evade taxes that accompanied it, and committed the parties to negotiating the peaceful resolution of their conflict within five years' time. The PLO and Israel recognized each other as legitimate partners for the first time, and the PLO agreed to renounce violence and terror. Over the next decade, substantially all Palestinian population centers in the West Bank and the Gaza Strip were turned over to a Palestinian Authority, with Yasser Arafat at its head. ${ }^{6}$

The Paris Protocol, signed in April 1994 as part of the Accords, set out to modify the economic relations between Israel and the PA. Paris marked a significant departure from the economic arrangements unilaterally imposed by Israel on the Palestinian territories. In the wake of the 1967 war, Israel introduced the shekel as a common currency, gradually linked Palestinian infrastructure to its own (severing it from Jordan and Egypt), permitted Palestinian labor mobility, and established a de facto customs union. At the same time, it introduced protectionist measures favoring its own economy and adopting restrictions on the Palestinian economy which suppressed local economic development. In particular, Israel denied the Palestinians the ability to stimulate their local economy, routinely denied permits to establish factories that would compete with Israeli producers, prevented the production and sale of agricultural products that would compete with Israeli producers, and underinvested in local infrastructure. $^{7}$

Paris specified almost every form of nonsecurity interaction between the parties, including water, electricity, energy, transport, communications, industry, and social welfare. It established a fund to support Palestinian economic development, with billions of dollars pledged by international donors, and created joint industrial zones near Palestinian population centers, in effect moving higher paid Israeli jobs 
closer to Palestinian workers. ${ }^{8}$

The bulk of the protocol, however, was concerned with trade, monetary and fiscal policy, and labor relations. First, Paris promised free labor movement for Palestinians to Israel, where workers earned 91 percent more. Although Palestinian laborers were permitted employment in Israel post-1967, Israel had begun to restrict their movement during the first intifada. Enshrining free mobility in the Accords, therefore represented a significant change in the labor regime. Second, the trade relationship was modified under Paris guaranteeing both sides free and preferential access to each other's markets. As well, the PA was given the ability to pursue independent trade arrangements with those states with which Israel did not enjoy diplomatic or economic relations. International trade was to be facilitated by the construction of a harbor and airport in Gaza and by a corridor linking Gaza to the West Bank. While the rules governing imports to the PA, including tariffs, were to be harmonized to the prevailing Israeli customs regime, a degree of autonomy over trade was to be granted to the PA in recognition of their special relationship with Arab and Muslim countries. Third, the PA was given authority to collect taxes, which previously accrued to Israeli authorities. Taxes and tariffs on goods imported through Israeli ports destined for the PA were to be collected by Israel and transferred to the PA, minus a three percent service charge. Similarly, payroll taxes and social security benefits collected in Israel on Palestinian employees were to be remitted to the PA. Furthermore, a Palestinian Monetary Authority (PMA) was to be established to oversee the Palestinian banking system and manage the PA's foreign currency reserves, although its ability to pursue an independent monetary policy was limited by the continued use of the Israeli shekel, and a full-throated fiscal policy would be constrained by the harmonization of tariffs and value-added taxes within a narrow range of the prevailing Israeli rates. ${ }^{9}$

Paris made extensive use of the preexisting economic arrangements (e.g., the maintenance of the customs union and the shekel as a common currency), but important differences were written into the agreement as well. Indeed, the customs union was modified extensively, providing Palestinians both, greater autonomy (through the ability to independently raise revenue, pursue local economic development, and trade with neighboring Arab states) and deeper economic integration with Israel. Unlike the customs union Israel unilaterally imposed post-1967, the Paris Protocol was the product of negotiations. With its promise of the free flow of goods, capital, and labor, and a common currency, Paris could properly be considered as a loose or modified economic and monetary union, one step shy of complete economic integration. ${ }^{10}$

\section{Discussion}

The Oslo negotiations, an unofficial exercise, departed dramatically from the official talks taking place simultaneously in Washington, D.C. First, the Oslo meetings were held in secret. This insulated the negotiators and allowed them considerable latitude. Second, unlike the official talks, from which the PLO was excluded, Oslo included the PLO. And third, they were initiated under a recently elected pro-peace Israeli Labor government, rather than by the United States and foisted on an unwilling Likud party, as the Washington talks had been. Finally, and perhaps most importantly, the Israeli side in Oslo consisted initially of academics based at the EU-funded Economic Cooperation Foundation (ECF) who reported to a Deputy Minister, Yossi Beilin, and to the Minister of Foreign Affairs, Shimon Peres, and all of whom - unlike the Israeli representatives in Washington-shared a deep-seated faith in the pacific effects of economic integration.

In devising the future Israeli-Palestinian economic relationship, the Oslo negotiators could choose from a range of possible alternatives, from complete economic separation to full integration. The Palestinian team desired increased autonomy from Israel on all matters, including the economy. For their part, the Israeli team favored economic integration in the form of a modified economic union which they saw as the most likely arrangement to confer mutual gains on the parties, thereby serving the goal of building confidence. Put differently, the Israelis believed that raising the Palestinian standard of living would reduce future violence by giving them "something to lose." Israeli negotiator Uri Savir explains that "fundamentalism ... thrives on poverty and despair." A modified economic union was a departure not only from the preexisting economic arrangements but also from the official talks where economic integration failed to emerge as an important negotiating plank. Indeed, economic issues rarely came up in Washington. Where they did, they tended to be lumped together with the issue of political independence by the Palestinian team, which Israel largely rejected. ${ }^{11}$

Extant theories of economic integration hold that deepening economic ties between countries yields both political and economic benefits. Integration is said to be mutually beneficial. On the economic side, neo-liberals argue that based on comparative advantage and economies of scale deeper integration through trade liberalization should bring with it higher productivity. On the political side, neo-functionalist theories suggest that economic and technical integration creates positive spillover effects that breed strong incentives for political integration. Neo-functionalism is based on Jean Monnet's approach of linking individual economic sectors across Europe (e.g., coal and steel) in the 1950s. The economic

The Economics of Peace and Security Journal — ISSN 1749-852X — https://www.EPSJournal.org.uk (C) EPS Publishing, 2018. All rights reserved. For permissions, email: ManagingEditor@EPSJournal.org.uk 
interdependence resulting from these linkages necessitated the creation of supra-national institutional capacity (i.e., legal regimes and dispute resolution mechanisms). In other words, political cooperation in Europe was a byproduct of initial technical and economic integration. Economic interdependence has therefore become synonymous with pacific behavior between states. $^{12}$

This was the vision to which the Israeli negotiators in Oslo subscribed. From their standpoint, economic cooperation would benefit both parties through increased productivity, trade, and employment. Israel would continue to have preferential access to the Palestinian market and generally reap the dividends of peace. The Palestinians would gain access to highly competitive foreign markets through Israel's free trade partners, as well as preferential access to the Israeli market. Greater integration was also supposed to provide Palestinians with technological, administrative, managerial, and organizational spillovers from the Israeli economy. Furthermore, the arrangement would give the Palestinians much needed time to develop the institutions and infrastructure necessary to manage their economy. According to David Brodet, the former Director General of the Israeli Ministry of Finance and an Oslo negotiator, "these were the issues that at that time both sides saw as win-win." Indeed, the agreement was remarkably optimistic and did not contain contingencies for deteriorating relations between the parties. ${ }^{13}$

The Israeli team's faith in the neo-functionalist approach was influenced by the European experience. They believed that economic integration would lead to positive spillover effects, thus reinforcing a fledgling peace, much as it had in postwar Europe. Indeed, the main intellectual figures behind the Oslo peace process made repeated and explicit references to it. For example, in his book The New Middle East, Israel's thenForeign Minister Shimon Peres describes a future in which Israelis and Arabs link their economies: "The very existence of this common market will foster vital interests in maintaining the peace over the long term." Israeli negotiator Ron Pundak expands: "European style economic integration-the New Middle East, as Peres called it-will reduce conflict." ${ }^{\text {"14 }}$

Similarly, the Israeli negotiator Yair Hirschfeld describes their efforts in Oslo to create positive spillover effects patterned after the European experience. Following neo-functionalist logic, he explained that spillovers were meant to occur initially through technical and economic integration, gradually leading the parties to overcome their entrenched partisan narratives and embrace the process in advance of final status talks. While Paris was merely an interim arrangement, the negotiators intended for it to form the basis of an ongoing cooperative relationship between the parties. Hirschfeld explains:

The picture you have from Europe was three phases. First was after World War Two. The leadership understood that they had to develop joint interests, mainly between Germany and France. The second stage was normalization. Societies slowly went along with it. The third phase was to look at the narratives. ${ }^{15}$

Not only did the EU provide a successful model of peaceful integration to be emulated, it had also been promoting its model of integration abroad for some time. The EU played host to a series of high-level talks of the Regional Economic Development Working Group (REDWG) coextensive with the talks then taking place in Washington. There, the Europeans quietly offered a competing, and in some ways novel, approach to conflict resolution. Unlike the Washington talks, which had begun to stalemate over the sticky issues of PLO involvement, refugees, borders, and others, these talks largely avoided issues of high politics. REDWG instead focused on joint technical and economic matters, such as the free flow of people, goods, services, and capital within the region, the development of infrastructure, the promotion of the private sector, investment, and others. Peters writes that the EU was informed by:

functionalist, liberalist conception of international cooperation and peace, according to which the enmeshing of the states in the region in an ever-widening web of economic, technical and welfare inter-dependencies would force them to set aside their political and/or ideological rivalries. The process of ongoing cooperation in areas of mutual concern would blur old animosities and create a new perception of shared needs. This interaction would be accompanied by a learning process which would foster a fundamental change in attitude and lead to a convergence of expectations and the institutionalization of norms and behavior ... functional cooperation would eventually spill over into regional peace. ${ }^{16}$

Furthermore, the EU hosted track-two diplomatic efforts and funded think tanks (such as the ECF) and development projects. It would later formalize these efforts through the office of the Special Representative. ${ }^{17}$

The Israeli team's adoption of the neo-functionalist model of integration has all of the hallmarks of a process of "diffusion". Diffusion occurs when ideas are disseminated from one actor to another. At the most basic level there needs to be contact for ideas to diffuse. Contact exposes an actor to a new or novel idea. This is often referred to as the "epidemic" 
or "epidemiological" model of diffusion. In this case, there was plenty of contact between the parties: The partnership between Israel and Europe (the EEC) date to 1964. The two reached a free trade agreement in 1975, and, during the period in question, the ECF, REDWG, and others further exposed the Israeli team to the European model of integration. ${ }^{18}$

Yet, while contact may be a necessary condition for the diffusion of ideas, on its own it is likely to be insufficient. Just because actors come into contact with new ideas does not mean that they will adopt them. Persuasion or social learning (socialization) are therefore often added to the epidemiological model of diffusion. Persuasion is the process by which communication leads to a change in beliefs. Persuasion occurs through deliberative argument rather than through material incentives (or disincentives) and is most likely to happen in less politicized and more insulated environments, and where both parties are from the same professional (epistemic) background, or where the source of ideas is from an in-group to which the other side wishes to belong. Again, the EU-funded ECF and REDWG both qualify as good sites of quiet deliberation, particularly for the newly elected Israeli Labor government which was keen to build closer relations with Western Europe. ${ }^{19}$

Finally, diffusion is said to be most likely to occur, and occur most rapidly, when the target is at a critical juncture and there appears to be a "goodness of fit". Policy failures, crises, or general uncertainty all motivate the search for new ideas, particularly from actors with a "recognized and authoritative claim to knowledge." These ideas are more likely to be adopted when "the target has few prior, ingrained beliefs that are inconsistent with the socialization agency's message," that is, when there is a similarity or a convergence, particularly in legal and bureaucratic areas. And indeed, the breakthrough in Oslo came about after one such critical juncture, the first intifada and the failure of the Washington talks. Furthermore, Israel was primed for a European model, having liberalized its economy over the past decade. And although Paris was not merely an extension of the economic conditions that Israel imposed after occupying Palestinian territories in 1967, it is worth noting again that the negotiators did not start with a tabula rasa. As I have argued, Paris modified and expanded upon the existing trade and monetary arrangements. In these ways, Paris converged with prevailing legal and bureaucratic spheres. $^{20}$

Substantially all of the modifications to the economic union were at the insistence of the PLO team. On the one hand, Palestinian negotiators placed substantial emphasis on maintaining or improving access to Israeli markets and on increasing their own level of economic development. On the other hand, they spent considerable energy to win increased economic independence, counter to an Israeli desire for deeper economic cooperation. In particular, the PLO team unsuccessfully demanded an independent currency rather than a monetary union, and a free trade agreement rather than a customs union, trappings of which they received via the trade rules described above. ${ }^{21}$

The diffusion model is informative in explaining why the idea of economic integration had less purchase on the Palestinian negotiators. First, they had significantly less contact with their European counterparts. Coming from an armed movement, well-entrenched in the Soviet camp, they were historically part of a substantially different epistemic background than the Europeans. As a result, there were far fewer sites for contact and social learning between them. Second, and more importantly, the notion of economic integration was strongly discordant with the PLO's longprofessed desire for sovereignty. David Brodet explains: "[A] free trade agreement or separate responsibilities for trade issues, automatically creates recognition of economic borders and economic borders lead to political borders." 22

\section{From negotiation to implementation}

While the process did trigger an huge influx of foreign aid to the fledgling PA and ushered in a period of sustained modernization and liberalization of the Palestinian economy, the later rejection by Israel of numerous aspects of the protocol largely negated any of the promised economic gains. After a period of rapid implementation beginning in 1994, which included the construction of industrial zones, the remittances of taxes and tariffs by Israel to the PA, the opening of crossings, and other integral elements of Paris, Israel halted further redeployments from Palestinian territories and began imposing closures on the Palestinian territories. In 1997, Israel also began periodically withholding tariff and tax revenues collected on behalf of the PA at Israeli ports of clearance, paying them late or not at all. These reversals were a result of several factors, including the wave of deadly suicide attacks aimed largely at Israeli civilians, the assassination of Israeli prime minister Yitzhak Rabin, under whose leadership the process was initiated, and the electoral defeat of the Labor party by the right-wing Likud party led by Benjamin Netanyahu, who repudiated the peace process. "The Oslo spirit ... was brushed aside," Pundak concludes. ${ }^{23}$

Foremost, wholesale border closures largely invalidated those portions of the agreement that granted free and preferential access to each others' markets, labor mobility, and trade between the PA and neighboring Arab states. Israel first began implementing periodic closures on the Palestinian 
territories in 1993, restricting the movement of goods and people. However, closures became a regular feature of Palestinian life only in the mid-nineties. Closures made Palestinian labor far less reliable for Israeli employers. Then-PA Minister of Finance Salam Fayyad noted: "Although there are many countries around the world with similarly high or even higher rates of unemployment, I know of none where the rate of unemployment can go up by 10-20 percentage points overnight." This instability caused Israeli employers to seek laborers elsewhere; immigration policies were changed to grant easier access to foreign rather than to Palestinian workers. The impact on the Palestinian economy was drastic: In 1992, more than a third of the Palestinian workforce was employed in Israel, contributing about 25 percent of GNP; in 1996, only 7 percent were similarly employed, contributing no more than 6 percent. $^{24}$

Trade also slowed considerably as a result of border closures and the failure to build international ports as promised in Paris. Because there was no direct access to third countries by air, land, or sea, closures often meant that exports could not find their way out of the Palestinian territories. However, even when closures were relaxed, complex and expensive export procedures - typically justified on grounds of security-were imposed in order to move Palestinian goods abroad through Israeli ports. For example, Palestinian-registered vehicles required special permits which often took several weeks to acquire and required lengthy inspection, and cargo originating in the Palestinian territories was not permitted carriage on passenger planes. Later, Palestinian vehicles were altogether excluded from entering Israel and costly back-to-back shipping measures were devised; the Gaza-West Bank corridor never materialized. Palestinian export costs are approximately 30 percent higher than they are for Israeli companies, and take 20 to 80 percent longer to reach their destination. As a result, from the start of the peace process onward, Palestinian exports declined nearly 50 percent by $1995 .^{25}$

The complexity of Paris also led to numerous disputes and unanticipated economic inefficiencies. For example, the leakages in tax and tariff collection as a result of Paris have been estimated to be as high as USD380 million per year, far outweighing the approximately USD48 million a year in savings by not setting up an independent customs authority. Similarly, the system devised to enable autonomous trade between the PA and Arab countries proved so difficult to implement that annual trade amounted to a paltry USD35 million, or just 1.1 percent of the total value of imported goods. And, while Paris specifically banned the use of standards as nontariff barriers (NTBs), contrary to the spirit of the agreements, Israel has been accused of using veterinary and phytosanitary standards to protect its domestic industries at the expense of the Palestinian economy. Aside from their potential to be used as NTBs, the Palestinians also complained that the imposition of Israeli standards constrained the development of their economy. Furthermore, Israel maintained extensive subsidies, particularly to its agricultural sector, during the peace process, diminishing the competitive advantage the much poorer Palestinian economy had. And, the absence of an independent currency deprived the Palestinian Monetary Authority (PMA) of the ability to set interest and exchange rates, limiting its ability to stimulate their own economy. Nor, for reasons outlined before, could the PMA increase tariffs to revenue maximizing levels, a strategy favored by many developing countries that often experience difficulties collecting taxes. The lack of a well-functioning dispute settlement mechanism meant that there was little the PA could do to address these issues. ${ }^{26}$

Finally, the lack of well-functioning and transparent government in the PA has also contributed to the economic decline in the Palestinian territories. Indeed, reports of endemic corruption in the PA have been widespread. For example, very large sums in government revenue and donor aid remain unaccounted for, having been used by Arafat for patronage, and inefficient economic monopolies granted based on political favoritism continue to have an outsized presence in several sectors of the Palestinian economy. The extent of the corruption later prompted sustained efforts by the international community to promote domestic reform. ${ }^{27}$

Aside from injections of foreign aid and some evidence of liberalization, few economic benefits accrued to the PA as a result of the peace process. Paris was overly complex and decidedly inefficient, and the PA was notoriously corrupt. However, it was the restriction on goods and labor-both of which were at the heart of the new economic relationship - that had the greatest impact on the Palestinian economy. The failure to implement the protocol as negotiated inflicted further damage. By the end of the 1990s, the Palestinian economy teetered. Employment in Israel disappeared, trade links with the outside world diminished, and GNP fell by approximately 30 percent. Indeed, Pundak concludes that "the economic situation on the ground for the Palestinians became worse than they were before [the Oslo peace process]. ${ }^{28}$

\section{Conclusion}

It is easy to lose sight of the significance of Paris nearly twenty-five years after it was signed. It is a challenge not to see the prevailing economic conditions in the Palestinian territories as an extension of those imposed by Israel fifty years ago when the occupation began. But Paris was a noteworthy departure: 
The protocol was not unilaterally imposed on the Palestinians, as the previous economic arrangements had been, and it was meant to be mutually beneficial. The Israeli team believed that economic cooperation would lead to positive spillover effects, thus reinforcing the fledgling peace process - an idea whose historical antecedents lie in postwar Europe. ${ }^{29}$

Contra neo-functionalists, Katherine Barbieri argues that economic interdependence may act to increase the likelihood of violent conflict rather than inhibiting it, as its neo-functionalist proponents suggest. She writes: "Asymmetrical economic interdependence creates tensions that may eventually manifest themselves in an inverse relationship between trade and conflictual interactions." Spillover effects can also run in the opposite direction, degrading relations, undermining cooperation, and entrenching conflict. The negotiators were, perhaps, overly sanguine about the promise of economic spillovers. After a brief period of implementation, Israel largely cast Paris aside, imposing wholesale closures on the Palestinian territories. As the Palestinian economy went into decline, so too did public support for a negotiated solution. In the words of the Israeli negotiator Moty Cristal, confidence building measures became "catastrophe building measures." Rather than having the anticipated effects, increased interdependence helped undermine the peace process. While the failure of the peace process was, perhaps, overdetermined, it is nevertheless a valuable exercise to reflect on how the economic protocol was a contributing factor. ${ }^{30}$

\section{Notes}

The authors gratefully acknowledges assistance from the Israel Institute, David Zarnett, Joseph Mackay, the participants of the Leonard Davis Institute roundtable at the Hebrew University of Jerusalem, and the anonymous reviewers of this journal.

1. Extension of conditions: See Arnon (2002, 2007); Farsakh (2008); Halper (2008); Levin (2007); Mitrani and Barnathan (2015, p. 300); Naqib (2003); Roy (1998, 1999, 2001).

2. Genealogical sensibility: Vucetic (2011). "History of the present": Roth (1981). Counter-history: Seidman (1994).

3. Neo-functionalist: See Haas (1958, 1964); Mitrany (1975). Diffusion of ideas: Checkel (1998, 1999a, 1999b, 2005).

4. Interviews: Interviews were conducted in Tel Aviv, East and West Jerusalem, and Ramallah in 2004 and 2011 with Ahmed Qurie (Abu Ala), Saeb Erakat, Yasser Abed Rabbo, David Brodet, Yossi Beilin, Yair Hirschfeld, Ron Pundak, Joel Singer, Uri Savir, Moti Cristal, Terje Roed-Larsen. Following the genealogical method, I treat these interviews as texts in need of interpretation. Private information: Fearon (1995); Schatz (2009). Triangulating evidence: Bennett and Checkel (2014); Checkel (2008).
5. As compared to: Newman and Yacobi (2004); Miller (1997); Peters and Dachs (2004). However, numerous studies examine the role of the EU in the Israeli-Palestinian peace process after Oslo. See, e.g., Adler (2006); Alpher (1998); Asseburg (2003); Bicchi (2006); Solingen (2003).

6. Five years' time: El-Jaafari and Elmusa (1995, p. 15); Gross (2000, p. 1555).

7. In the wake: Arnon and Weinblat (2001); Astrup and Desus (2001); Schiff(2002, p. 3). Prevented competition: Al-Botmeh and Kanafani (2006); Arnon (1997, 2007); Arnon and Weinblatt (2001, pp. 293, 295); Beilin (1999, p. 14); Brynen, Diwan, and Shaban (1999, p. 6); El-Jaafari and Elmusa (1995, p. 17); Gazit (1995); Gross (2000, p. 1551); Kleiman (1994, pp. 349-350; 1999, p. 247). Underinvested: Arnon (2007); Gross (2000, p. 1584).

8. Donors: Brynen (1996a, 1996b, 2000). Industrial zones: Shafir and Peled (2000).

9. Workers earned more: Schiff (2002, p. 26). Harmonized customs regime rules: Gross (2000, p. 1560). Payroll tax remittances: Kleiman (1994).

10. Product of negotiations: Arnon and Weinblatt (2001). Lose union: Kleiman (1994) argues that Paris contain elements of a common market as regards the movement of labor, a free trade agreement as regards the trade arrangements with countries that Israel did not enjoy economic or diplomatic relations, and economic independence as regards the prohibition of those goods finding their way into the Israeli market (pp. 371-372). It is also worth noting that the agreement itself referred to economic "envelopes" rather than "unions" which, according to Kleiman (1994, p. 370; 2010, p. 251), are associated with agreements between sovereign states. Integration: Balassa (2013).

11. Building confidence: Shafir and Peled (2000). "Something to lose": Gross (2000, p. 1587). Savir quote: Savir (1998, p. 29). Largely rejected: Ashrawi (1996).

12. Extant theories: Balassa (2013). Neo-liberals: See, e.g., Friedman (2009); Hayek (1944). On the pacifying effects of economic development, see Gartzke (2007); Hegre (2000); McDonald (2007, 2009). Neo-functionlist: Haas (1958, 1964); Mitrany (1975).

13. Preferential access: Arnon and Spivak (1998). Greater integration: Banister, et al. (2001, p. 93); Gross (2000, p. 1586). Brodet quote: Brodet (2004, p. 4). No contingencies: Arnon and Weinblatt (2001). However, the Israeli negotiator Ron Pundak, explained that "the Israeli negotiators were told to keep all options open, from a Palestinian state to continued occupation" (2012). Because Oslo did not introduce borders it did not prejudice the outcome of final status talks and had the merit of being reversible, should circumstances necessitate it (Kleiman 1994, p. 370; 2010, p. 251; Arnon and Weinblatt 2001, p. 291).

14. Peres quote: Peres and Naor (1993, p. 99). Pundak quote: (2012, interview); also see Scheel (2010).

The Economics of Peace and Security Journal — ISSN 1749-852X — https://www.EPSJournal.org.uk (C) EPS Publishing, 2018. All rights reserved. For permissions, email: ManagingEditor@EPSJournal.org.uk 
15. Hirschfeld (2012, interview).

16. REDWG instead focused: Peters (1996). Quote: Peters (1996, p. 66).

17. Furthermore: Asseburg (2003); Diez, Stetter, and Albert (2006). Formalize: Diez and Pace (2007).

18. Diffusion: Checkel (1998, 1999a, 1999b, 2005). Model of diffusion: Checkel (1999a). Plenty of contact: Miller (2004).

19. Change in beliefs: Risse (2000); Checkel (2008). Persuasion quotes: Checkel (2008). Professional background: Haas (1992). Wishes to belong: Checkel (2008).

20. Goodness of fit: Haas (1992); Checkel (1999a). Policy failures quote: Haas (1992, pp. 3-4). Likely adopted quote: Checkel (1999a, p. 87). Convergence: Strang and Meyer (1993). Israel was primed: Aharoni (1998); Shafir and Peled (2000).

21. Insistence by PLO team: Kleiman (1994, p. 351). Access to Israeli market: Kleiman (1994); Arnon and Weinblatt (2001). Increasing level of development: Abbas (1995, p. 300). Israeli desire: Gross (2000, p. 1610); Arnon and Weinblatt (2001, p. 296); Schiff(2002, p. 33). Unsuccessfully demanded: The protocol did promise a "possibility of introducing ... [a] Palestinian currency" in the future, but this was never realized (Paris Protocol, 1994, Art. 7b).

22. European counterparts: Al-Dajani (1980); Kirişci (1986); Norton and Greenberg (1989); Dannreuther (1998); Miller (2004). Quote: Brodet (2004, p. 2). Also see Rabbo (2004).

23. Influx of aid: Arnon states that foreign aid amounted to "close to \$300 per person per year," making the PA the world's highest per capita aid recipient (Arnon, 2007, p. 590). Sustained modernization: Schiff (2002, p. 17). Paying late: Arnon (2007, p. 588). Attacks aimed at civilians: Arnon and Weinblatt (2001, p. 301). Repudiation: This is, of course, not to mention the Israeli violations of the Accords, most notably the increase in the number of West Bank settlements during the same period. Quote: Pundak (2004, p. 4).

24. Border closures: Usher (1996, p. 36). Restricting movement: Akkaya, et al. (2011). Salam Fayyad quote: Fayyad (1999, p. 5). Immigration policies changed: Gross (2000, p. 1581). Drastic impact: Gross (2000, p. 1561).

25. Not permitted carriage: Banister, et al. (2001, pp. 67, 71). Corridor never materialized: Al-Botmeh and Kanafani (2006). Export cost and duration: Banister, et al. (2001, p. 52). Export decline: Arnon and Weinblatt (2001, p. 300).

26. Leakages: Al-Botmeh and Kanafani (2006). Savings: Schiff (2002, pp. 10, 25). Trade with Arab countries: Schiff (2002, p. 19). Ban of NTBs: Paris, Article III, 10. (Mis)use of standards: Gross (2000: 1551); Beilin (1999: 14); Brynen, Diwan, and Shaban (1999, p. 6). Palestinians also complained: Schiff (2002, p. 15). Absence of independent currency: Banister, et al. (2001). No revenue maximization: Gross (2000, p. 1604). Lack of dispute settlement mechanism: Paris created a joint economic committee charged with resolving matters that might arise during implementation. But the committee could not effectively arbitrate disputes as both sides enjoyed equal representation and therefore had a veto over any decisions. In the end, the committee did not address the majority of the issues that arose during the implementation phase and at no point attempted to renegotiate the terms of the protocol. See Al-Botmeh and Kanafani (2006); Arnon and Weinblatt (2001); El-Jaafari and Elmusa (1995).

27. Endemic corruption: Halevi (1998); Ramahi (2013). Patronage: Brynen (1995). Monopolies: El-Jaafari and Elmusa (1995, p. 23). Efforts to promote reform: PLC (2013); Fayyad (1999, p. 3).

28. Greatest impact: Astrup and Dessus (2001, p. 1). GNP fell: Roy (1999, p. 76); Levin (2007); Miarri and Sauer (2011). Quote: Pundak (2004, p. 5).

29. Mutually beneficial: Arnon (2007).

30. Barbieri quote: Barbieri (1996, p. 30). Decline: Nachtwey and Tessler (2002). Cristal quote: Cristal (2004, p. 4).

\section{References}

Abbas, M. 1995. Through Secret Channels: The Road to Oslo. Senior PLO Leader Abu Mazen's Revealing Story of the Negotiations with Israel. Reading, UK: Garnet.

Adler, E. 2006. The Convergence of Civilizations: Constructing a Mediterranean Region. Toronto: University of Toronto Press.

https://doi.org/10.3138/9781442621121

Aharoni, Y. 1998. "The Changing Political Economy of Israel." The Annals of the American Academy of Political and Social Science. Vol. 555, No.1, pp. 127-146. https://doi.org/10.1177/0002716298555001009

Akkaya, S., N. Fiess, B. Kaminski, and G. Raballand 2011. Fragility and Conflict in Palestine: The Costs of the Closures Regime on West Bank and Gaza. Oxford, UK: Oxford University Press.

Al-Botmeh, S, and N. Kanafani. 2006. "The Paris Economic Protocol and Beyond: In Search of an Optimal Trade Arrangement." The Palestine Yearbook of International Law Online. Vol. 14, No. 1, pp. 75-97.

Al-Dajani, A. 1980. "The PLO and the Euro-Arab Dialogue." Journal of Palestine Studies. Vol. 9, No. 3, pp. 81-98. https://doi.org/10.2307/2536551

Alpher, J. 1998. "The Political Role of the European Union in the Arab-Israel Peace Process: An Israeli Perspective." The International Spectator. Vol. 33, No. 4, pp. 77-86. https://doi.org/10.1080/03932729808456835

Arnon, A. ed. 1997. The Palestinian Economy: Between Imposed Integration and Voluntary Separation. New York: Brill.

Arnon, A. 2002. "The Implications of Economic Borders Between Israel and Palestine." Palestine-Israel Journal of Politics, Economics, and Culture. Vol. 9, No. 3. [Online]

Arnon, A. 2007. "Israeli Policy Towards the Occupied Palestinian Territories: The Economic Dimension, 1967-2007." The Middle East Journal. Vol. 61, No. 4, pp. 
$573-595$.

https://doi.org/10.3751/61.4.11

Arnon, A. and A. Spivak. 1998. "Economic Aspects of the Oslo Peace Process." Palestine-Israel Journal of Politics, Economics, and Culture. Vol. 5, No. 3 \& 4. [Online]

Arnon, A. and J. Weinblatt. 2001. "Sovereignty and Economic Development: The Case of Israel and Palestine." The Economic Journal. Vol. 111, No. 472, pp. 291-308. https://doi.org/10.1111/1468-0297.00631

Ashrawi, H. 1996. This Side of Peace: A Personal Account. New York: Simon and Schuster.

Asseburg, M. 2003. "The EU and the Middle East Conflict: Tackling the Main Obstacle to Euro-Mediterranean Partnership." Mediterranean Politics. Vol. 8, No. 2, pp. 174-193. https://doi.org/10.1080/13629390308230011

Astrup, C. and S. Dessus. 2001. "Trade Options for the Palestinian Economy: Some Orders of Magnitude." Washington, D.C.: The World Bank.

Balassa, B. 2013. The Theory of Economic Integration. London, UK: Routledge.

Banister, G., H. Davoodi, F. Fischer, E. Jenker, M. Said, R. Vadivieso, and U.E. von Allemen. 2001. "West Bank and Gaza Economic Performance, Prospects, and Policies Achieving Prosperity and Confronting Demographic Challenges." Washington, D.C.: International Monetary Fund.

Barbieri, K. 1996. "Economic Interdependence: A Path to Peace or a Source of Interstate Conflict?" Journal of Peace Research. Vol. 33, No. 1, pp. 29-49. https://doi.org/10.1177/0022343396033001003

Beilin, Y. 1999. Touching Peace: From the Oslo Accord to a Final Agreement. London: Weidenfeld \& Nicolson.

Bennett, A. and J. Checkel, eds. 2014. Process Tracing. Cambridge, UK: Cambridge University Press. https://doi.org/10.1017/CBO9781139858472

Bicchi, F. 2006. "Our Size Fits All: Normative Power Europe and the Mediterranean." Journal of European Public Policy. Vol. 13, No. 2, pp. 286-303. https://doi.org/10.1080/13501760500451733

Brodet, D. 2004. Interview with author. 1 April 2004.

Brynen, R. 1995. "The Neopatrimonial Dimension of Palestinian Politics." Journal of Palestine Studies. Vol. 25, No. 1, pp. 23-36.

https://doi.org/10.2307/2538102

Brynen, R. 1996a. "International Aid to the West Bank and Gaza: A Primer.” Journal of Palestine Studies. Vol. 25, No. 2, pp. 46-53. https://doi.org/10.2307/2538183

Brynen, R. 1996b. "Buying Peace? A Critical Assessment of International Aid to the West Bank and Gaza." Journal of Palestine Studies. Vol. 25, No. 3, pp. 79-92. https://doi.org/10.2307/2538261

Brynen, R. 2000. A Very Political Economy: Peacebuilding and Foreign Aid in the West Bank and Gaza. Washington, D.C.: The United States Institute of Peace Press.
Brynen, R., I. Diwan, and R. Shaban. 1999. "Development under Adversity: The Palestinian Economy in Transition." Washington, D.C.: Palestine Economic Policy Research Institute and World Bank.

Checkel, J. 1998. "The Constructive Turn in International Relations Theory." World Politics. Vol. 50, No. 2, pp. 324-348.

https://doi.org/10.1017/S0043887100008133

Checkel, J. 1999a. "Norms, Institutions, and National Identity in Contemporary Europe." International Studies Quarterly. Vol. 43, No. 1, pp. 84-114. https://doi.org/10.1111/0020-8833.00112

Checkel, J. 1999b. "Social Construction and Integration." Journal of European Public Policy. Vol. 6, No. 4, pp. $545-560$. https://doi.org/10.1080/135017699343469

Checkel, J. 2005. "Getting Socialized to Build Bridges: Constructivism and Rationalism, Europe and the Nation-State." International Organization. Vol. 59, No. 4, pp. 1045-1079.

Checkel, J. 2008. "Process Tracing," pp. 114-127 in J. Checkel, ed. Qualitative Methods in International Relations. A Pluralist Guide. London, UK: Palgrave MacMillan. https://doi.org/10.1057/9780230584129_8

Cristal, M. 2004. Interview with author. 12 March 2004.

Dannreuther, R. 1998. The Soviet Union and the PLO. Berlin: Springer.

https://doi.org/10.1007/978-1-349-26216-8

Diez, T. and M. Pace 2007. "Normative Power: Europe and Conflict Transformation." London, UK: Palgrave Macmillan.

Diez, T., S. Stetter, and M. Albert. 2006. "The European Union and Border Conflicts: The Transformative Power of Integration." International Organization. Vol. 60, No. 3, pp. 563-593. https://doi.org/10.1017/S0020818306060218

El-Jaafari, M. and S. Elmusa. 1995. "Power and Trade: The Israeli-Palestinian Economic Protocol." Journal of Palestine Studies. Vol. 24, No. 2, pp. 14-32. https://doi.org/10.2307/2537730

Farsakh, L. 2008. "The Political Economy of Israeli Occupation: What is Colonial About It?" The Electronic Journal of Middle Eastern Studies. Vol. 8 (Spring), pp. 41-58.

Fayyad, S. 1999. "Statement at the Second Annual Europe-Palestine Conference." 30 September - 2 October 1999. Ramallah.

Fearon, J. 1995. "Rationalist Explanations for War." International Organization. Vol. 49, No. 3, pp. 379-414. https://doi.org/10.1017/S0020818300033324

Friedman, M. 2009. Capitalism and Freedom. Chicago, IL: The University of Chicago Press.

Gartzke, E. 2007. "The Capitalist Peace.” American Journal of Political Science. Vol. 51, No. 1, pp. 166-191. https://doi.org/10.1111/j.1540-5907.2007.00244.x 
Gazit, S. 1995. The Carrot and the Stick: Israel's Policy in Judaea and Samaria, 1967-68. Washington, D.C.: Bnai Brith Books.

Gross, O. 2000. "Mending Walls: The Economic Aspects of Israeli-Palestinian Peace." American University International Law Review. Vol. 15, No. 6, pp. 1539-1626.

Haas, E. 1958. The Uniting of Europe: Political, Social, and Economic Forces, 1950-1957. Stanford, CA: Stanford University Press.

Haas, E. 1964. Beyond the Nation-State: Functionalism and International Organization. Stanford, CA: Stanford University Press.

Haas, P. 1992. "Introduction: Epistemic Communities and International Policy Coordination." International Organization. Vol. 46, No. 1, pp. 1-35. https://doi.org/10.1017/S0020818300001442

Halevi, I. 1998. "Self-Government, Democracy, and Mismanagement Under the Palestinian Authority." Journal of Palestine Studies. Vol. 27, No. 3, pp. 35-48. https://doi.org/10.2307/2537833

Halper, J. 2008. An Israeli in Palestine: Resisting Dispossession, Redeeming Israel. London: Pluto Press.

Hayek, F. 1976 [1944]. The Road to Serfdom. London: Routledge.

Hegre, H. 2000. "Development and the Liberal Peace: What Does it Take to be a Trading State?" Journal of Peace Research. Vol. 3, No. 1, pp. 5-30. https://doi.org/10.1177/0022343300037001001

Kirişci, K. 1986. The PLO and World Politics: A Study of the Mobilization of Support for the Palestinian Cause. London: Pinter.

Kleiman, E. 1994. "The Economic Provisions of the Agreement Between Israel and the PLO." Israel Law Review. Vol. 28, Nos. 2-3, pp. 347-373. https://doi.org/10.1017/S0021223700011687

Kleiman, E. 1999. "Fiscal Separation with Economic Integration: Israel and the Palestinian Authority," pp. 246-263 in A. Razin and E. Sadka, eds. The Economics of Globalization: Policy Perspectives from Public Economics. Cambridge, UK: Cambridge University Press.

Levin, J. 2007. "Accord to Discord: A Political Economy Approach to the Oslo Process." Palestine-Israel Journal of Politics, Economics, and Culture. Vol. 14, No. 3, pp. 62-68. [Online]

McDonald P. 2007. "The Purse Strings of Peace." American Journal of Political Science. Vol. 51, No. 3, pp. 569-582. https://doi.org/10.1111/j.1540-5907.2007.00268.x

McDonald, P. 2009. The Invisible Hand of Peace. Cambridge, UK: Cambridge University Press. https://doi.org/10.1017/CBO9780511818301

Miaari, S., and R. Sauer. 2011. "The Labor Market Costs of Conflict: Closures, Foreign Workers, and Palestinian Employment and Earnings." Review of Economics of the Household. Vol. 9, No. 1, pp. 129-148. https://doi.org/10.1007/s11150-009-9081-6

Miller, B. 1997. "Great Powers and Regional Peacemaking:
Patterns in the Middle East and Beyond." Journal of Strategic Studies. Vol. 20, No. 1, pp. 103-142. https://doi.org/10.1080/01402399708437666

Miller, R. 2004. "The PLO Factor in Euro-Israeli Relations, 1964-1992." Israel Affairs. Vol. 10, Nos. 1-2, pp. 123-155. https://doi.org/10.1080/13537120412331321401

Mitrany, D. 1975. The Functional Theory of Politics. London: Robertson.

Mitrani, M. and G. Press-Barnathan. 2015. "The (De) Construction of 'Economic Peace': 'Economic Peace' Strategies in the Israeli-Palestinian Conflict," pp. 194-212 in C. Lutmar and B. Miller, eds. Regional Peacemaking and Conflict Management: A Comparative Approach. London: Routledge.

Nachtwey, J. and M. Tessler. 2002. "The Political Economy of Attitudes Toward Peace Among Palestinians and Israelis." Journal of Conflict Resolution. Vol. 46, No. 2, pp. 260-285. https://doi.org/10.1177/0022002702046002005

Naqib, F. 2003. "Economic Aspects of the Palestinian-Israeli Conflict: The Collapse of the Oslo Accord." Journal of International Development. Vol. 15, No. 4, pp. 499-512. https://doi.org/10.1002/jid.999

Newman, D. and H. Yacobi 2004. "The EU and the Israel/Palestine Conflict: An Ambivalent Relationship." Working Paper 4. Working Paper Series in EU Border Conflicts Studies. Birmingham: Department of Political Science and International Studies, University of Birmingham.

Norton, A. and M. Greenberg. 1989. The International Relations of the Palestine Liberation Organization. Carbondale, IL: Southern Illinois University Press.

Peres, S. and A. Naor. 1993. The New Middle East. New York: Harper Element.

Peters, J. 1996. "Pathways to Peace: The Multilateral Arab-Israeli Peace Talks." London: The Royal Institute of International Affairs.

Peters, J. and G. Dachs. 2004. "Israel and Europe, the Troubled Relationship: Between Perceptions and Reality." Working Paper of the Israeli-European Policy Network. Herzliya: Friedrich-Ebert Foundation.

Pundak, R. 2012. Communication with author. 8 April 2012.

Rabbo, Y. 2004. Interview with author. 2 May 2004.

Ramahi, S. 2013. "Corruption in the Palestinian Authority." Middle East Monitor. Special Report. Available at https://www.aman-palestine.org/data/itemfiles/b2a7e241 322895ba53fdd6425a55c40a.pdf [accessed 15 November 2017].

Risse, T. 2000. "'Let's Argue!': Communicative Action in World Politics.” International Organization. Vol. 54, No. 1, pp. 1-39. https://doi.org/10.1162/002081800551109

Roth, M. 1981. "Foucault's 'History of the Present'." History and Theory. Vol. 20 No. 1, pp. 32-46. https://doi.org/10.2307/2504643

Roy, S. 1998. "The Palestinian Economy after Oslo.” Current 
History. Vol. 97, No. 615, pp. 19-25.

Roy, S. 1999. "De-development Revisited: Palestinian Economy and Society since Oslo." Journal of Palestine Studies. Vol. 28, No. 3, pp. 64-82.

https://doi.org/10.2307/2538308

Roy, S. 2001. "Palestinian Society and Economy: The Continued Denial of Possibility." Journal of Palestine Studies. Vol. 30, No. 4, pp. 5-20. https://doi.org/10.1525/jps.2001.30.4.5

Savir, U. 1998. The Process: 1,100 Days that Changed the Middle East. New York: Vintage Books.

Schatz, E. 2009. "What Kind(s) of Ethnography does Political Science Need?" pp. 303-318 in E. Schatz, ed. Political Ethnography: What Immersion Contributes to the Study of Power. Chicago, IL: The University of Chicago Press. https://doi.org/10.7208/chicago/9780226736785.001.0001

Scheel, N. 2010. Economic Integration Leading to Peace? Shimon Peres' Vision of A New Middle East. Munich: GRIN Verlag.

Schiff, M. 2002. "Trade Policy and Labor Services: Final Status Options for the West Bank and Gaza." Development Research Group of the World Bank. Washington, D.C.: World Bank. https://doi.org/10.1596/1813-9450-2824

Seidman, S. 1994. The Postmodern Turn: New Perspectives on Social Theory. Cambridge, UK: Cambridge University Press. https://doi.org/10.1017/CBO9780511570940

Shafir, G. and Y. Peled, eds. 2000. The New Israel: Peacemaking and Liberalization. Boulder, CO: Westview Press.

Solingen, E. 2003. "The Triple Logic of the European-Mediterranean Partnership: Hindsight and Foresight." International Politics. Vol. 40, No. 2, pp. 179-194.

https://doi.org/10.1057/palgrave.ip.8800020

Strang, D. and J. Meyer 1993. "Institutional Conditions for Diffusion." Theory and Society. Vol. 22, No. 4, pp. 487-511. https://doi.org/10.1007/BF00993595

Usher, G. 1996. "Closures, Cantons and the Palestinian Covenant." Middle East Report. Vol. 26 (Summer), No. 199, pp. 33-37. Available at http://www.merip.org/mer/ mer199 [accessed 15 November 2017].

Vucetic, S. 2011. "Genealogy as a Research Tool in International Relations." Review of International Studies. Vol. 37, No. 3, pp. 1295-1312.

https://doi.org/10.1017/S0260210510000938 